\title{
Parenting as an Acculturation Process: The Case of a Group of Indonesian Families
}

\author{
Meilanny Budiarti Santoso ${ }^{1} \&$ Nurliana Cipta Apsari ${ }^{2}$ \\ ${ }^{1}$ Social Welfare Department, University of Padjadjaran, Indonesia \\ ${ }^{2}$ Family and Child Welfare Research Centre, University of Padjadjaran, Indonesia \\ Correspondence: Nurliana Cipta Apsari. Tel: 62-813-2071-3795 E-mail: nurliana.cipta.apsari@unpad.ac.id
}

Received: July 25, 2018 Accepted: July 31, $2018 \quad$ Online Published: August 31, 2018

doi:10.5539/ass.v14n9p1 URL: https://doi.org/10.5539/ass.v14n9p1

\begin{abstract}
Understanding role of the mothers in delivering their functions within families is an important factor to the formulation of profile of their children. Three main roles of mothers studied included parenting, learning at home and communicating, emphasizing to parenting only. The research was conducted to 13 mothers and children who are in their first grade of elementary school using in-depth interview and observation techniques. The research found that all informants are housewives, with level education of elementary school, and in their late thirties. The research confirm all of the children in the study are interacting with their mothers. The informats utilize trial-error strategy, and does not have sufficient comprehension in playing their roles. In this study, parenting function is conducted through verbal actions such as giving advices, prohibition, and forcing the children. However, there is also mothers who involve the children without forces, thus bringing awareness of the child to help the mother. Informants are not too actively involve in learning at home and communicating with school is limited to taking the child to school. Children experience psychic issues because of their environment, and academic achievement are below average. These indicated the need of performing competency enhancement for the mothers to help them in delivering their roles.
\end{abstract}

Keywords: parenting, role of mothers, family functioning, parents involvement

\section{Introduction}

Family serves as the smallest institution in community, yet hold a biggest responsibility to ensure the ability of every members to live a life. In order to achieve the responsibility, the family has functions and every family members have roles to play, within the family, community and society. As Parson (1951) mentioned that individuals in social environment have different and separated roles, and the responsibility to fulfil the role is needed to ensure the live sustainability.

In Asian countries, including Indonesia, specifically in Java Island, the community still hold the believe that fathers will take on the role as the breadwinner, yet mothers will take on the roles of parenting at home, as housewives. The division of role between fathers-mothers; husbands-wives implicitly creating situations where mothers will spend more time with the children, moreover during breastfeeding and when the child is still young. The similar situation is also found at many Chinesse and Malaysian families residing at Malaysian coast (Noor, 1999).

Currently, mothers have also take on role as breadwinner and worked professionally outside their houses, however, the believe of parenting as mothers' responsibilities is still relatively attached to them, thus in practice, third parties often invited to take care the children (maid, parent, siblings or putting the child into child care institution). The role in certain condition is deliverable by others, however, the function of the mothers is still attached, how a mother can play her role effectively thus the child development is achieved to the fullest (biologically and psychologically) despite the situation faced. Mothers in this study are those with school age children. According to Erikson (in Woody, 2003; Apsari, 2015) children of school age are categorized as middle childhood (6-12 years old), with characteristics of high curiousity, able to make friend and learning new things. Fass \& Mason (2000) as cited by Hutchinson (2003) said that in general, midlle childhood is considered as the time for educating, playing, and socializing in their daily lives. The role of the mothers in this study is to support the process of acculturation of the children, thus various values can serve as the ransom for the children to 
achieve their fullest time during the middle childhood.

Historically, a child will have more interaction with his/her mother, either for meeting the physiological need (breastfeed, food, clothing), or socializing the value system in the family. Hayes \& Pittelkow (1993) argue that cultural and religious values are adopted by children since their psychological development emerge during childhood and that family plays big roles in determining the values the children adopted. Family is the first and upmost place for a child to learn how to interact with other people as family members. At this stage the value system built during the interaction with the mother will encounter other value system of the family members (father, sibling, grandparent, or other people who reside at the same houshold). In these assembling value system in the family, our attention is not only toward the form of the values, but also toward the child ability to have adaptive resilience toward value system outside his/her value system. This is important, because when a child interaction scope is wider, during school or playing with friends, the child will again, encounter different value system.

The family members background (economy, social, culture and personal) especially parent, play significant role toward the child orientation of literacy. Personal and economical background of the parent are two influential factors toward child education. Both components contribute to creating a conducive home environment for the children (Teale \& Sulzbu, 1986).

The more the child grows, will influence the form of parental involvement as form of their responsibility in developing the child education and psychosocial. Mo and Singh (2008) stated three form of parent involvement, which are parent-child relationship, parents' involvement at school, and parent's education aspiration for their children.

The Harvard Family Research Project (2006) also defined three form of parents involvement, which are consist of (i) parenting, (ii) home-school relationships, and (iii) responsibility for learning outcomes. Specifically for parenting, the involvement is in the shape of parent-child relationship and participation in child-centered activities. Parenting is a process of family involvement in introducing and embedding attitudes, values and parent practices in raising their children.

Children are the foundation for social environment because they are the subject that will take on the future. Thus, variety of activities are conducted in order to prepare the children for the future, including the effort for their formal education. In their early lives, education process is started from what have the children learnt from their parents, within their family environment. In the future, this early education will influence their future education, even influencing the children's social aspect in the future.

Raharjo (1993) states education is a designed effort in order to shape the children's behavior based on their nature, including hospitality, self discipline, belief (mental), socialization and motivating. Thus the parent role is important for children's education. In this regard, mother as internal household manager plays very important role in family education. Emotional and psychological closeness with the children will make the mothers into main motivator in acculture the values to the children.

Covey in Yusuf (2011: 47-48) describe four principles of the roles of the family, those are:

1. Modeling (Example of trustworthiness). Parent is the role model for their children, thus children will learn how to be proactive, compassionate and respectful to others.

2. Mentoring, which is the ability to build relationship, emotional investment or protection to others in a deep, honest, personal and unconditional ways. Parent is the first resource for the children to develop the child's feelings: feeling secure or unsecure, loved or despised.

3. Organizing, where family is like a company that need team work and cooperation among members in fulfilling their tasks or achieving family needs.

4. Teaching. Parent serves as teacher for the children about basic regulation in lives, thus the children understood and obey them. Parent serves as teacher to create 'conscious competence' in child's lives, thus the children understand on what they are doing and the reasons underlining their conduct.

Refer to Indonesian Government Rules No.87 year 2014, family is defined as the smallest unit in a community, which consist of husband-wife or husband, wife and children or a father and his child/ren or a mother with her child/ren (Act 1 point 6). Family as an institution for its members, have functions and roles. There are at least 8 main function of a family as defined by the Rules, which are (1) Faith, (2) socio cultural, (3) compassion, (4) protection, (5) reproduction, (6) socialization and education, (7) economy, and (8) environmental guidance. The focus of this study is on sociocultural and socialization and education functions. 
When an individual or institution runs its functions and roles, thus fundamentally they are in a process of fulfilling their wish, and in order to meet their needs. Maslow (1943) categorized the individual needs in a hierarchical formulation where one particular need has to be achieved before achieving the needs afterward. Thus the behavior will centered on the achievement of needs at lower level before then continue to achieve the higher levels.

The Maslow Hierarchy Needs (1943) are consist of basic needs, safety, relationship, comfortable and self actualization. The first four needs will drive every individuals to make an effort to be achieved for survival, yet the highest needs, which is self actualization putting more emphasize on personality quality.

Matsumoto \& Juang (2008) believed that every person is bond by his/her biological imperative for survival, and this is in connection with his/her ability to adapt with his/her environment and the context of his/her current situation. Thus, this biological bond will be connected with social motives, which could also bring about social problems that need to be addressed. The solution of the variety of social problems then will formulate cultures.

The older the age, the more a person achieve experiences, thus the cultural profile of the person is more expressed. A child which is still in the care of the mother does not show the cultural profile, thus the process of the mother in playing the role of educating the child is seen as an acculturation process, where the younger person learn and adopt the way the culture shows and behavior of the cultural translation. The child involvement in the early acculturation process is not only important to inherit certain culture, but also serves as the supporting capacities for the child for his/her future and start to widening the social and variety of interaction areas.

The acculturation process has two different yet connected components, which are intercultural adaption and intercultural adjustment. When a child is still in the care and guidance of a mother, the social context faced is still relatively protected and under controlled thus the adaptation process and adjustment will not be painful. However, when a child starts to interact with his/her outside world, then the role of the child capacity in adaptation and self adjustment with the surrounding environment is important. Based on the explanation above, it is clear that the mother roles in educating her children especially in building the child capacity to adapt and adjust which enable the child to be independently joint with the child social environment is crucial, thus important to be studied, especially to young mothers with new children. This article will be important for those who are interested in child development, parent-child relationship as well as those who concerns on Asian families context.

\section{Method}

The study is conducted using qualitative approach, which explore the conduct of mothers role in parenting. The function studied is limited to parenting function conducted by mothers, covering: (1) ways the mothers teach honesty (2) ways the mothers teach hospitality (3) ways the mothers teach the children to report what have been done (4) ways the mothers teach about compassion (5) things that most taught by mothers about attending (6) to whom children taught to share. The informants were determined from a process of drawing and coloring activities for all of the first grade students of the school. From the activity, there was 13 children identified with uniqeness of attitude and behavior during the drawing and coloring process and they were eye-catching to be explored more. After that, the mother of the 13 children were being determined as the informants of the study on parenting process. The children informants are from elementary school SDN Hanjuang Samijaya, Kelurahan Cihanjuang Kecamatan Parongpong Kabupaten Bandung Barat. The school is public school located in the middle of housing environment at Sub-urban of a small Cimahi City, thus the pupils are coming from the surrounding neighbourhood.

The data is collected primarily and secondarily. Primary data is taken from interviews with mothers and their children. The process of interview with mothers was conducted at home, while interviewing children were conducted at school. To complete the writing of this article, secondary data is also used, especially from literature in the form of books or article journals on parenting and acculturation process through parenting. The interview guide is including the aspects of how the mothers teach honesty, hospitality, reporting activities, compassion, attending, and sharing. The guide is also used to the children to gain answers from their point of view.

The instrument used is interview guidance and some tools for interviewing children, such as plain paper, drawing books, color pencils. The interview to mothers were conducted at their houses, yet the children are interviewed during school hours. After data collection is done, the data then being processed and classified based on the theme of the study. After being clasified, the data is analysed in accordance with the research context. 


\section{Results}

The research shows that most mothers spend most of their time with their children and actively involve with their children's lives everyday. The informants are all housewives and spend most times at home with their children, yet the fathers work outside the house as the breadwinner for the family. This is common situation in many Asian countries, including Indonesia. Table 1 below show the informants education background characteristic:

Table 1.

\begin{tabular}{cc}
\hline Level of education & N \\
\hline Elementary School & 7 \\
Junior High School & 4 \\
Senior High School & 2 \\
Total & 13 \\
\hline
\end{tabular}

Source: Study Result, 2017

The table shows that none of the informants reach higher education, which also limits their capacity to work outside the house, which is also evidenced from the informants occupation as housewives is reaching $100 \%$. The mothers' level of education will also influence the level of knowledge and capacity in educating their children. However, the mothers as housewives show the existence of intense connection with their children at home.

Another basic characteristic obtained from the study is age of the informants. Table 2 below shows the category of the informants based on their age.

Table 2.

\begin{tabular}{cc}
\hline Age (years old) & N \\
\hline Below 30 & 2 \\
$31-40$ & 6 \\
$41-50$ & 4 \\
Above 51 & 1 \\
Total & 13 \\
\hline
\end{tabular}

Source: Study Result, 2017

Almost all of the informants are in the age category of 31-40 years old. This means that they are no longer young therefore it is assumed that they should already know and aware of how to parent their children. The following section will explore the conduct of parenting function performed by the mothers, covering (1) ways the mothers teach honesty (2) ways the mothers teach hospitality (3) ways the mothers teach the children to report what have been done (4) ways the mothers teach about compassion (5) things that most taught by mothers about attending (6) to whom children taught to share.

In ways the mother teach honesty, the informants usually giving advice when a child is lying and some informants also describe the way they teach honesty by relating it with religion. The mothers give advice when they found the children's behavior is different with values and norms of common people. The mothers do not apply any educating method with specific technique that connect the behavior with everyday practices. Thus, the mother only told the children about the values and norms and giving advice is the only resort they are aware of. Yet, for young children, advice is abstract and difficult to digest because their brain development is not yet capable of understanding advice is connecting with their behavior.

The similar way is also appear during the way the mothers teach hospitality to their children. The mothers will response to "bad" behavior of the children and will provide advice, although this time, the mothers show some example of "good" behavior expected of the children. The mothers have no plan in raising their children, such as what cultural values or norms that they wish their children could learn from the daily interaction of mothers and 
children. This is interesting and support the fact that many young parents do not know how to do effecting parenting and that they will parent their children the way they were parented by their parents.

The ways the mother teach their children to "report" or convey to the mothers about what have been done is described by only convey/report when being asked. The investigation shows that there is no learning process of building the child capability to convey/report their activities to the mothers. Thus, the child only tell stories of their activities when being asked. This means, when the mothers are busy and does not have opportunities to ask, the mothers are missing a great opportunity to build communication with their children, thus enabling the children to be open and enjoy communication with other people.

In teaching the child to show compassion, the mothers usually give example, although based on the interview, there are also mothers who do not teach their children to show compassion because they believed that their children already have compassion without being taught by them, including their compassion toward the parent. As for parenting function of teaching children to share, mothers firstly teach the children to share their toys and food with their peers. At this time of age, the children are starting to build friendship and learning how to share is important. School is the new environment outside their home, the ability of the children to adjust and adapt with new rules and new values at school will also influence the children happiness at school. This also apparent at the study that the children are taught to share to their friends and then siblings. However, the way the mothers taught to share and show compassion is by telling the children to do so, and the mothers did not explain the importance of sharing and showing compassion to others. Again, the mothers lose the opportunity to build communication with the children on those aspects which in the end, will resulting the child only show compassion or want to share if the mothers are around.

During the parenting process, the children will show their reponse toward the "orders" from their mothers. It is evidence from the research that when a child disobey the "order", the mother will force the child to do so and at some point let the child do whatever they want, although the way the child behave is against the "good" values or norms. The effect of this process can be felt by the mothers and the children as well, from the acculturation process perspective, the process will minimally formulate the cultural shape in the children, because the mothers are continuously in a state of negative confrontation with their children due to misunderstanding. The way the mothers ask and told the children what to do and sometimes involving harsh forcement, will create tension on the relationship between mothers and children, because the children are expected do adaptation and adjustment toward their mothers wishes and orders.

The observation result shows that there is also a child involvement, but the involvement is limited to asking the child to assist with the mothers' needs, thus when there is a collision with the child's own activity, conflict then appears. This study confirm with the concept that most young mothers do not have sufficient knowledge to conduct the education function.

\section{Discussion}

From the research we can find that mothers told the children what to do and there was no explanation of why the children should do what they are being told to do. Children response positively or negatively to the orders. When the children response in a positive manner, the mother will complement the child, however, when the child response negatively, the mothers sometimes do abusive behavior to show her power as the mother, which then will force the children do whatever being told to by the mother. This situation is forming learning process in the child as mentioned by Covey in Yusuf (2011) that family play the role of modelling. Meanwhile, when a home is considered as the first place for acculturations, then, the variety of conditions as explained above will elevate the risk of losing the opportunity for the children to build their capacity for adapatation and adjustment outside their home in the future, which will elevate the risk of emerging social problems when the children interact with outside environment which clearly stated by Hayes \& Pittelkow (1993) that family plays big role in determining the values the children adopt. There is a proverb in Sundanese (West Java Province Indonesia) "kaciwit kulit kabawa daging" or "katempuhan buntut maung" which explain that when a child is having problems, then the parent will also infuenced by the problems. From the proverb, it is clear that in West Java Province, the parents will always protect the children in order to avoid the children running into problems, which in the end will also be the parents problems. This research shows the real situation of a small group of mothers in practicing parenting in small area of West Java Province, however, Indonesia is a large country with large population, thus the parenting practice may differ from one family to others. This opens up the possibility of studying parenting practice in Indonesian context with larger population as informants.

The children in the study are in their first grade, however, whether the child is the first child or not is uncovered in this research, thus further study is needed to investigate whether the parenting roles of the mothers will be 
different on every child's position in the family in Asian or Indonesian context.

Sociocultural function of parenting from mothers will influence the way the children interact with outside world. Thus it is important for the parents to escalate their understanding toward their children development that is apparent from the child behavior. Bad and good terms are very subjective terms, the parents should use the child developmental age as the perspective of parenting to avoid conflict. In order for the mothers to transfer their "good" culture toward their children, they have to open their mind on the culture that is exist outside home, thus the "good" culture is no longer the mothers domain, but the society. Thus this research recommend the enhancement of the mothers ability in parenting and adding the skills in parenting with positive discipline. With positive discipline, the mothers will be taugh how to build communication and enhance their understanding on child development, thus in the end will provide a positive acculturation process between the mothers and children.

\section{Acknowledgments}

The study is funded by University of Padjadjaran as part of internal grant for lecturers of University of Padjadjaran, thus the authors are very grateful for that.

\section{References}

Apsari, Nurliana Cipta. (2015). Hak Anak Perspektif Pekerjaan Sosial. Jatinangor: Unpad Press.

Benjamin, L. A. (1993). Parents' Literacy Their Children's Success In School: Recent Research, Promising Practices, and Research Implications. Education Research Report. Retrieved from https://files.eric.ed.gov/fulltext/ED363441.pdf

Close, R. (2004). Television and Language Development in the Early Years: A Review of the Literature. London: National Literacy Trust. Retrieved from https://files.eric.ed.gov/fulltext/ED541608.pdf

Farley \& Skidmore. (1994). Introduction to Social Work (6th ed.). New Jersey: Prentice Hall

Han, Y. S., \& Jun, W. P. (2013). Parental Involvement in Child's Development: Father Vs Mother. Open Journal of Medical Phycology, (2), 1-6. Retrieved from http://file.scirp.org/pdf/OJMP_2013102116042191.pdf

Hayes, B. C., \& Pittelkow, Y. (1993). Religious Belief, Transmission, and the Family: An Australian Study. Journal of Marriage and the Family, LV, 755-766. Retrieved from https://www.jstor.org/stable/353355

Kemdikbud. (2016). Kemitraan Sekolah dengan Keluarga dan Masyarakat. Jakarta: Dirjen Paud dan Dikmas.

Keown, L. J., Woodward, L. J., \& Field, J. (2001). Language Development of Pre-School Children Born To Teenage Mothers. Infant and Child Development, (10), 129-145. https://doi.org/10.1002/icd.282

Maslow, A. H. (1943). A Theory of Human Motivation. Psychological Reviews, 4(50), 370-396.

Matsumoto, D., \& Juang, L. (2008). Culture \& Phycology (4th ed.). USA: Thomson Wadsworth.

Mo, Y., \& Singh, K. (2008). Parents' Relationship and Involvement; Effect on Students' School Engagement and Performance. Research in Middle Level Education Online, 31(10), 1-1. https://doi.org/10.1080/19404476.2008.11462053

Noor, N. M. (1999). Roles and Women's Well-Being: Some Preliminary of Child-Rearing Responsibility. Sex Roles, (41), 123-145. Retrieved from https://www.researchgate.net/profile/Noraini_Noor/publication/ 251347555_Roles_and_Women\%27s_Well-Being_Some_Preliminary_Findings_from_Malaysia/links/5673 5c2f08aedbbb3f9f97ce/Roles-and-Womens-Well-Being-Some-Preliminary-Findings-from-Malaysia.pdf

Pan, B. A., Rowe, M. L., Singer, J. D., \& Snow, C. E. (2005). Maternal Correlates of Growth in Toddler Vocabulary Production in Low-Income Families. Child Development, (76), 763-782. https://doi.org/10.1111/1467-8624.00498-i1

Parson, T. (1951). The Social System. Illinois: The Free Press.

Peraturan Pemerintah Republik Indonesia Nomor 87 (2014). Tentang Perkembangan Kependudukan Dan Pembangunan Keluarga, Keluarga Berencana, Dan Sistem Informasi Keluarga.

Raharjdo, M. B. (1993). Peranan Keluarga Dalam Pendidikan Anak. Analisis CSIS, XXII(3) Mei-Juni, 221-232.

Sclafani, J. D. (2004). The Educated Parent: Recent Trends In Raising Children. Connecticut: Praeger Publishers.

Teale, W. H., \& Sulzby, E. (1986). Background and Young Children's Literacy Development. Emergent Literacy: Writing and Reading. New Jersey: Ablex Publishing Corporation. 
Warga, R. B. (1983). Personal Awareness: A Psychology of Adjustment. Boston: Hoghton Mifflin Company.

Weiss, H. B., Caspe, M., \& Lopez, M. E. (2006). Family involvement makes a difference: Evidence that family involvement promotes school success for every child of every age. Harvard Family Research Project Series. Harvard Graduate School of Education. 1: 1-8. [cited 2017 Jun 5].

Woody, D. J. (2003). Ch. 4 Early Childhood. Dalam Hutchinson, Dimensions of Human Behavior: The Changing Life Course, hlm (pp. 159-195). Thousand Oaks: Sage Publications.

Yusuf, S. (2011). Psikologi Perkembangan Anak dan Remaja. Bandung: Rosdakarya.

\section{Copyrights}

Copyright for this article is retained by the author(s), with first publication rights granted to the journal.

This is an open-access article distributed under the terms and conditions of the Creative Commons Attribution license (http://creativecommons.org/licenses/by/4.0/). 